\title{
Changes in fatty acid composition in nutritional fatty degeneration of the liver
}

\author{
1. Effect of starvation*
}

\author{
By ABRAHAM S. FEIGENBAUM AND HANS FISHER \\ Department of Poultry Science, Rutgers, The State University, New Brunswick, \\ New Fersey
}

(Received I2 December I961-Revised 3 I August 1962)

The development of a fatty liver during starvation has been demonstrated in guineapigs (Statkewitsch, I894; Mottram, I 909; Best \& Campbell, 1938), dogs (Statkewitsch, 1894), cats (Statkewitsch, I894; Gershoff, Andrus \& Hegsted, 1959), rabbits (Mottram, I909), mice (Best \& Campbell, 1938), rats (Best \& Ridout, 1938-9; Dible, 1932) and man (Larson, I946; Gabuzda, 1958). However, in the course of a series of experiments on the effects of protein depletion (Summers \& Fisher, I960) it was noted that chickens did not develop a fatty liver during starvation. It was the purpose of our study to examine the fatty acid composition of the liver of chickens during starvation and to explore age and sex as influencing factors in this connexion.

\section{EXPERIMEN'T AL}

First series of experiments. For an initial comparison of normal and starved birds results from various experiments were pooled, so that normal values were available for sixteen separate groups of five birds each and values for animals starved for 5 days were obtained for ten separate groups of five birds each. Females, 2 weeks old, from a Columbian $\times$ New Hampshire cross were used. During an initial 2-week feeding period a standard maize-soya-bean growing diet (Table I) was given. In one trial male chickens were compared with females from the same hatch and of the same body-weight to investigate possible sex differences. The birds were killed at the beginning or end of a 5-day starvation period. Water was available throughout. The weight of the birds killed after 5 days of starvation was as nearly as possible the same as the mean weight of the birds before any were removed.

Second series of experiments. Two experiments were carried out in which 2-week-old females from a Columbian $\times$ New Hampshire cross were killed during a 5-day starvation period. Five birds were selected daily as described above.

Third series of experiments. In the first experiment of this series a group of twelve 2-year-old Leghorn cocks of similar body-weight was used. Each day during a 5-day starvation period two cocks were killed. In the second experiment ten adult female

\footnotetext{
- Paper of the Journal Series, New Jersey Agricultural Experiment Station. Supported in part by
} grants-in-aid from the National Science Foundation G-I 1399 and U.S. Public Health Grant A-4904. 
Long-Evans rats of similar body-weight were starved for a 3 -day period. Two animals were killed before starvation or after $\mathrm{I}$ or 3 days of starvation.

Procedure. All animals were killed with chloroform and their livers were removed immediately. The livers of the growing birds were pooled but those of adult cocks and rats were treated individually. The pooled or individual livers were weighed and homogenized, and portions were frozen for later analysis. The frozen livers were freeze-dried and then extracted with a 2: I mixture of chloroform and methanol overnight. The sample was then extracted with a second portion of solvent for an additional $2 \mathrm{~h}$ with intermittent shaking. The dried extract was then re-extracted with light petroleum (b.p. $30-60^{\circ}$ ). After evaporation of this solvent, iodine values were determined on the residue by the Wijs method (Association of Official Agricultural Chemists, 1955). Throughout the extraction and the analytical procedures to which fat was subjected, oxygen-free nitrogen was used to minimize oxidative changes. Polyunsaturated fatty acids having two to six double bonds were determined in the residue by the alkali isomerization method of Luddy, Barford, Riemenschneider \& Evans (1958). The amount of monoenoic acid was calculated as the difference between the amount of polyunsaturated and total unsaturated fatty acids, the latter having been derived from the iodine value. We recognize that a small error is incurred in this procedure by neglecting to account for the unsaturation of cholesterol. The amount of saturated fatty acids, in turn, was calculated as the difference between that of total unsaturated fatty acids and the weight of the fat sample. Duplicate analyses of all samples (pooled or individual) were made throughout these studies.

\section{Table I. Composition of the standard maize-soya-bean growing diet}

\begin{tabular}{lc}
\multicolumn{1}{c}{ Ingredient } & $\begin{array}{c}\text { Amount } \\
(\%)\end{array}$ \\
Maize meal & 55.77 \\
Wheat middlings & $5 \cdot 00$ \\
Dried whey & $2 \cdot 50$ \\
Dried maize distillers solubles & $2 \cdot 50$ \\
Meat meal & $2 \cdot 50$ \\
Fish meal & 3.75 \\
Lucerne & $2 \cdot 50$ \\
Soya-bean meal & $23 \cdot 13$ \\
Dicalcium phosphate & $1 \cdot 00$
\end{tabular}

\begin{tabular}{lc}
\multicolumn{1}{c}{ Ingredient } & $\begin{array}{c}\text { Amount } \\
(\%)\end{array}$ \\
Limestone & $1 \cdot 00$ \\
Trace-mineral mixture & 0.10 \\
Sodium chloride & 0.25 \\
Vitamin supplement/100 lb finished diet \\
Vitamin A & 80000 i.u. \\
Cholecalciferol & 15000 i.u. \\
Riboflavin & $30 \mathrm{mg}$ \\
Cyanocobalamin & $0.2 \mathrm{mg}$ \\
Choline chloride & $15 \mathrm{~g}$
\end{tabular}

\section{RESULTS}

First series of experiments. The mean results for all the starvation experiments with growing female chickens are shown in Table 2. Liver size as a percentage of bodyweight decreased significantly $(P<0.05)$ during starvation. Although the amount of liver fat as a percentage of liver weight remained essentaa"y unchanged, it decreased sharply on an absolute basis. The iodine value increased significantly during starvation $(P<0.05)$. As indicated by the fatty acid analyses, the increase was primarily due to a differential retention of some of the more highly unsaturated acids (the tetra-, penta-, and hexa-enoic acids). The trienoic acid fraction disappeared completely during starvation from all the liver-fat samples analysed. 
The last two columns of Table 2 give the comparison for male and female chickens. The males had more liver fat, which was slightly more saturated than that of the females, as indicated by its lower iodine value. Otherwise there were no marked differences between the sexes, both groups showing a differential retention of the tetra- and hexa-enes and complete absence of trienes when compared to the o-day values, column $\mathrm{I}$. It should be noted that the values in column 3 do not necessarily correspond to those of column 2 since the former values represent only one of the ten groups used in calculating the latter values.

Table 2. Effect of starvation of chickens for 5 days on body-weight, liver weight and fat content, and composition of liver fatty acids, and comparison of results for males and females

\begin{tabular}{|c|c|c|c|c|}
\hline & \multirow{2}{*}{\multicolumn{2}{|c|}{$\begin{array}{l}\text { Summary" } \\
\text { Days of fast }\end{array}$}} & Females $\dagger$ & Males† \\
\hline & & & \multicolumn{2}{|c|}{ Days of fast } \\
\hline Measurement & o & 5 & 5 & 5 \\
\hline $\begin{array}{l}\text { Body-weight }(\mathrm{g}) \\
\text { before starvation } \\
\text { after starvation }\end{array}$ & x66 \pm 5 & $\begin{array}{l}168 \pm 12 \\
113 \pm 6\end{array}$ & $\begin{array}{l}156 \\
106\end{array}$ & $\begin{array}{l}156 \\
112\end{array}$ \\
\hline $\begin{array}{l}\text { Liver weight as } \\
\text { percentage of body- } \\
\text { weight }\end{array}$ & $4.6 \pm 0.2$ & $2 \cdot 6 \pm 0.1$ & $2 \cdot 7$ & $2 \cdot 6$ \\
\hline $\begin{array}{l}\text { I,iver fat: } \\
\text { as percentage of } \\
\text { wet liver weight }\end{array}$ & $5.2 \pm 0.2$ & $4.8 \pm 0.3$ & $5 \cdot 0$ & $5 \cdot 9$ \\
\hline $\begin{array}{l}\text { as mg/liver } \\
\text { iodine value }\end{array}$ & $\begin{array}{c}401 \pm 39 \\
71 \pm 1\end{array}$ & $\begin{array}{r}134 \pm 7 \\
86 \pm 4\end{array}$ & $\begin{array}{r}139 \\
85\end{array}$ & $\begin{array}{r}173 \\
75\end{array}$ \\
\hline $\begin{array}{l}\text { Fatty acids: } \\
\text { as percentage of fat }\end{array}$ & & & & \\
\hline & $\begin{array}{l}52 \cdot 4 \pm 2 \cdot 4 \\
31 \cdot 7 \pm 2 \cdot 9\end{array}$ & $\begin{array}{l}60 \cdot 5 \pm 2 \cdot 1 \\
18 \cdot 0 \pm 2 \cdot 8\end{array}$ & $\begin{array}{l}48 \cdot 4 \\
35 \cdot 2\end{array}$ & $\begin{array}{l}55 \cdot 7 \\
29 \cdot 2\end{array}$ \\
\hline dienes & $8.2 \pm 0.7$ & $6.4 \pm 0.4$ & $5 \cdot 2$ & 4.5 \\
\hline trienes & $I \cdot 3 \pm 0 \cdot I$ & 0 & $\circ$ & 0 \\
\hline tetraenes & $3.4 \pm 0.3$ & $5.9 \pm 0.5$ & $4 \cdot 5$ & $4 \cdot 3$ \\
\hline pentaenes & $I \cdot 0 \pm 0 \cdot 1$ & $1 \cdot 7 \pm 0.1$ & $\mathrm{I} \cdot 3$ & $I \cdot I$ \\
\hline hexaenes & $2 \cdot 0 \pm 0.2$ & $7 \cdot 5 \pm 0 \cdot 6$ & $5 \cdot 5$ & $5 \cdot 2$ \\
\hline $\begin{array}{l}\text { as } \mathrm{mg} / \mathrm{g} \text { liver } \\
\text { saturated }\end{array}$ & $27 \cdot 2+1 \cdot 3$ & $28 \cdot 7 \pm 2 \cdot 1$ & 24.0 & $32 \cdot 8$ \\
\hline monoenes & $17 \cdot x \pm 2 \cdot 1$ & $9 \cdot 0 \pm 1 \cdot 7$ & $17 \cdot 5$ & $17 \cdot 2$ \\
\hline dienes & $4^{1} \pm 0.3$ & $3.0 \pm 0.2$ & $2 \cdot 6$ & $2 \cdot 6$ \\
\hline trienes & $0.7 \pm 0.05$ & 0 & 0 & 0 \\
\hline tetraenes & $1.8 \pm 0.1$ & $2.8 \pm 0.2$ & $2 \cdot 2$ & $2 \cdot 6$ \\
\hline pentaenes & $0.5 \pm 0.05$ & $0.8 \pm 0.05$ & 0.7 & 0.6 \\
\hline hexaenes & $1 \cdot 0 \pm 0 \cdot 1$ & $3.5 \pm 0.2$ & $2 \cdot 7$ & $3 \cdot 0$ \\
\hline
\end{tabular}

- Mean values with their standard errors for sixteen groups of five 2-week-old female chickens before starvation and for ten groups of five female chickens starved for 5 days.

$\uparrow$ Mean values for duplicate analyses for one group of five birds.

Second series of experiments. Table 3 gives the mean results of the two experiments in which livers were analysed daily. As expected, there was a progressive decrease in body-weight during starvation. Liver weight decreased at a slightly faster rate than did body-weight. The liver fat content, as a percentage of the wet liver weight, decreased to the end of the $4^{\text {th }}$ day and then increased again. In absolute terms, 
however, the liver fat content decreased continuously. The total unsaturation of the liver fat, as measured by its iodine value, increased slightly with time during starvation but decreased again on the last day.

Table 3. Daily changes in body-weight, liver weight and fat content, and composition of liver fatty acids during starvation in the growing female chicken

(Mean values for two groups of five)

$\quad$ Measurement
Body-weight $(\mathrm{g}):$
before starvation
after starvation
Liver weight as
percentage of body-weight
Liver fat:
as percentage of wet liver
weight
as mg/liver
iodine value
Fatty acids:
as percentage of fat
saturated
monoenes
dienes
trienes
tetraenes
pentaenes
hexaenes
as mg/g liver
saturated
monoenes
dienes
trienes
tetraenes
pentaenes
hexaenes

\begin{tabular}{|c|c|c|c|c|c|}
\hline & & & fast & & \\
\hline 0 & I & 2 & 3 & 4 & 5 \\
\hline 176 & 176 & ${ }_{1} 85$ & 176 & 180 & $\begin{array}{r}78 \\
\end{array}$ \\
\hline- & 157 & 146 & $13^{6}$ & 128 & 120 \\
\hline 3.0 & 3.0 & $2 \cdot 8$ & $2 \cdot 9$ & $2 \cdot 7$ & $2 \cdot 5$ \\
\hline $5 \cdot 2$ & $5 \cdot 2$ & $5 \cdot 0$ & 4.4 & $4 \cdot 3$ & $4 \cdot 8$ \\
\hline 271 & 236 & 186 & 167 & $13^{8}$ & 134 \\
\hline 74 & 76 & $8 \mathrm{I}$ & 82 & 82 & 77 \\
\hline $57 \cdot 8$ & $63 \cdot 7$ & $6_{3} \cdot 8$ & 64.8 & $65 \cdot 6$ & $68 \cdot 7$ \\
\hline $24^{\circ} 0$ & $16 \cdot 3$ & 15.6 & 14.6 & 13.7 & $I I \cdot 2$ \\
\hline $\begin{array}{l}8 \cdot 4 \\
0.8\end{array}$ & $7 \cdot 5$ & $6 \cdot 3$ & 5.9 & 5.5 & $5 \cdot 3$ \\
\hline $\begin{array}{l}0.8 \\
3.6\end{array}$ & $4 \cdot 6$ & $\begin{array}{l}0 \\
5 \cdot 3\end{array}$ & $\begin{array}{l}0 \\
5 \cdot 2\end{array}$ & $\begin{array}{l}0 \\
5.2\end{array}$ & $\begin{array}{l}0 \\
5 \cdot 2\end{array}$ \\
\hline$I \cdot 6$ & $1 \cdot 7$ & $1 \cdot 6$ & $1 \cdot 8$ & $1 \cdot 6$ & $1 \cdot 7$ \\
\hline $4 \cdot 0$ & $6 \cdot 2$ & $7 \cdot 2$ & $7 \cdot 8$ & $8 \cdot 4$ & $7 \cdot 8$ \\
\hline 30.5 & $33 \cdot 3$ & $31 \cdot 6$ & $28 \cdot 8$ & $28 \cdot 4$ & 33.5 \\
\hline $12 \cdot 6$ & $8 \cdot 5$ & $7 \cdot 6$ & 6.4 & $5 \cdot 9$ & $5 \cdot 3$ \\
\hline 4.4 & 4.0 & 3.0 & $2 \cdot 6$ & $2 \cdot 3$ & $2 \cdot 6$ \\
\hline 0.4 & 0 & 0 & 0 & 0 & 0 \\
\hline $\mathrm{I} \cdot 8$ & $2 \cdot 3$ & $2 \cdot 6$ & $2 \cdot 4$ & $2 \cdot 3$ & $2 \cdot 6$ \\
\hline 0.8 & 0.9 & 0.8 & 0.8 & 0.8 & 0.8 \\
\hline $2 \cdot 1$ & $3 \cdot 2$ & $3 \cdot 6$ & 3.5 & $3 \cdot 6$ & $3 \cdot 6$ \\
\hline
\end{tabular}

The amounts of fatty acids in the liver fat, expressed as a percentage of fat content, decreased markedly with time in the mono- and di-enoic acid fractions. The trienoic acid fraction disappeared completely within the first $24 \mathrm{~h}$ of starvation. The pentaenoic acid fraction remained relatively constant, whereas the amount of the saturated and tetraenoic acid fractions and of the hexaenoic acid fraction, with the exception of the final sample, increased continuously.

When the fatty acid concentrations were expressed in absolute terms $(\mathrm{mg} / \mathrm{g}$ fresh liver), those of the saturated fatty acids fluctuated within narrow limits. The concentrations of the other fatty acid fractions when expressed on an absolute basis followed the same pattern as that noted for them in relative terms. With the exception of the absence of an increase in the pentaenoic acid fraction, these results are in essential agreement with those previously cited ('Table 2).

Third series of experiments. Table 4 gives the mean results of the liver-fat studies for adult cocks and rats. The birds lost $10 \%$ of their body-weight and about the same 
Table 4. Daily changes in body-weight, liver weight, liver fat and fatty acids during starvation in the adult cock and adult female rat

(Mean values for two animals)

\begin{tabular}{|c|c|c|c|c|c|c|c|c|c|}
\hline \multirow[b]{2}{*}{ Measurement } & \multicolumn{6}{|c|}{$\begin{array}{l}\text { Adult cocks } \\
\text { Days of fast }\end{array}$} & \multicolumn{3}{|c|}{$\begin{array}{c}\text { Adult rats } \\
\text { Days of fast }\end{array}$} \\
\hline & 0 & I & 2 & 3 & 4 & 5 & 0 & $\mathbf{I}$ & 3 \\
\hline $\begin{array}{l}\text { Body-weight }(\mathrm{g}) \text { : } \\
\text { before starvation } \\
\text { after starvation }\end{array}$ & 3085 & $\begin{array}{l}3095 \\
3025\end{array}$ & $\begin{array}{l}3090 \\
2900\end{array}$ & $\begin{array}{l}3090 \\
2878\end{array}$ & $\begin{array}{l}3090 \\
2800\end{array}$ & $\begin{array}{l}3095 \\
2765\end{array}$ & 289 & $\begin{array}{l}289 \\
269\end{array}$ & $\begin{array}{l}289 \\
249\end{array}$ \\
\hline $\begin{array}{l}\text { Liver weight as } \\
\text { percentage of body- } \\
\text { weight }\end{array}$ & $I \cdot 2$ & $1 \cdot 3$ & $1 \cdot 4$ & $1 \cdot 2$ & $I \cdot 3$ & $1 \cdot 2$ & 3.5 & $3 \cdot 1$ & $4 \cdot 1$ \\
\hline $\begin{array}{l}\text { Liver fat: } \\
\text { as percentage of wet } \\
\text { liver weight }\end{array}$ & 4.9 & $4 \cdot 3$ & $4 \cdot 5$ & 47 & $4 \cdot 6$ & $4 \cdot 6$ & $6 \cdot 2$ & $5 \cdot 5$ & $6 \cdot 0$ \\
\hline $\begin{array}{l}\text { as } \mathrm{mg} / \text { liver } \\
\text { iodine value }\end{array}$ & $\begin{array}{r}1804 \\
85\end{array}$ & $\begin{array}{r}1695 \\
87\end{array}$ & $\begin{array}{r}1792 \\
83\end{array}$ & $\begin{array}{r}1617 \\
85\end{array}$ & $\begin{array}{r}1670 \\
84\end{array}$ & $\begin{array}{r}1452 \\
82\end{array}$ & $\begin{array}{r}629 \\
60\end{array}$ & $\begin{array}{r}462 \\
76\end{array}$ & $\begin{array}{r}601 \\
76\end{array}$ \\
\hline $\begin{array}{l}\text { Fatty acids: } \\
\text { as percentage of fat }\end{array}$ & & & & & & & & & \\
\hline $\begin{array}{l}\text { saturated } \\
\text { monoenes } \\
\text { dienes }\end{array}$ & $\begin{array}{r}45 \cdot 7 \\
34 \cdot 5 \\
9 \cdot 2\end{array}$ & $\begin{array}{r}41 \cdot 4 \\
39 \cdot 1 \\
9 \cdot 4\end{array}$ & $\begin{array}{r}49 \cdot 2 \\
3 I \cdot 3 \\
8 \cdot 0\end{array}$ & $\begin{array}{r}52 \cdot 3 \\
26 \cdot 4 \\
8 \cdot 4\end{array}$ & $\begin{array}{r}51 \cdot 3 \\
28 \cdot 5 \\
8 \cdot 0\end{array}$ & $\begin{array}{r}41 \cdot 1 \\
43 \cdot 9 \\
6 \cdot 0\end{array}$ & $\begin{array}{r}78 \cdot 1 \\
5 \cdot 3 \\
4 \cdot 4\end{array}$ & $\begin{array}{l}70 \cdot 5 \\
8 \cdot 3 \\
6 \cdot 4\end{array}$ & $\begin{array}{r}75 \cdot 5 \\
2 \cdot 0 \\
6 \cdot 8\end{array}$ \\
\hline trienes & $2 \cdot 3$ & $2 \cdot 5$ & $2 \cdot 3$ & $2 \cdot 2$ & $2 \cdot 4$ & $2 \cdot 2$ & 0 & 0 & 0 \\
\hline tetraenes & $4 \cdot 6$ & $4 \cdot 2$ & $4 \cdot 6$ & 5.7 & 4.9 & 3.4 & 5.0 & $6 \cdot 6$ & $5 \cdot 2$ \\
\hline pentaenes & $1 \cdot 3$ & $1 \cdot 3$ & I. 5 & $1 \cdot 8$ & $1 \cdot 8$ & $1 \cdot 2$ & $1 \cdot 8$ & $1 \cdot 6$ & $1 \cdot 3$ \\
\hline hexaenes & $2 \cdot 4$ & $2 \cdot 2$ & 3.0 & $3 \cdot 2$ & $3 \cdot 2$ & $2 \cdot 2$ & $5 \cdot 4$ & $6 \cdot 6$ & $9 \cdot 2$ \\
\hline $\begin{array}{l}\text { as } \mathrm{mg} / \mathrm{g} \text { liver } \\
\text { saturated }\end{array}$ & 22.4 & 17.6 & $22 \cdot 0$ & 24.4 & $23 \cdot 3$ & 18.8 & $48 \cdot 2$ & $38 \cdot 7$ & $45 \cdot 2$ \\
\hline monoenes & 17.0 & 16.8 & $14 \cdot 1$ & $12 \cdot 3$ & $13 \cdot 1$ & 19.9 & $3 \cdot 2$ & $4 \cdot 6$ & $1 \cdot 2$ \\
\hline dienes & 4.5 & $4 \cdot 1$ & $3 \cdot 7$ & $3 \cdot 9$ & $3 \cdot 6$ & $2 \cdot 7$ & $2 \cdot 7$ & 3.5 & 411 \\
\hline trienes & $I \cdot I$ & $1 \cdot 0$ & $I \cdot O$ & $I \cdot O$ & $1 \cdot 0$ & $1 \cdot 0$ & 0 & $\circ$ & 0 \\
\hline tetraenes & $2 \cdot 3$ & $1 \cdot 8$ & $2 \cdot 1$ & $2 \cdot 7$ & $2 \cdot 3$ & $I \cdot 6$ & $3 \cdot 1$ & $3 \cdot 6$ & $3 \cdot 1$ \\
\hline pentaenes & 0.7 & 0.6 & 0.7 & 0.8 & 0.8 & 0.5 & $I \cdot I$ & 0.9 & 0.8 \\
\hline hexaenes & $1 \cdot 2$ & 0.9 & $1 \cdot 3$ & I. 5 & $I \cdot 5$ & $I \cdot I$ & $3 \cdot 3$ & $3 \cdot 6$ & $5 \cdot 5$ \\
\hline
\end{tabular}

proportion of liver weight. The amount of fat in the liver decreased on the average by less than $10 \%$, the low value on the last day being due to the relatively small liver of one of the two birds killed. The small liver contained a much smaller quantity of fat (I $39 \mathrm{mg}$ ), even though the fat accounted for $4.6 \%$ of its weight. The other bird killed on that day had $1765 \mathrm{mg}$ liver fat, which in all respects was similar to that of the other birds killed earlier. Examination of the results of the fatty acid analyses showed no consistent patterns of change during starvation either in specific acids or in overall saturation, the iodine values remaining constant.

In the rat experiment there was an initial small decrease in liver size after I day of starvation, followed by a considerable enlargement of the liver on the $3^{\text {rd }}$ day of fasting. Liver fat content also decreased during the Ist day, only to increase again by the 3 rd day. The total unsaturation, as shown by the iodine values, increased considerably during starvation.

The content of saturated fatty acids showed little change, whereas that of the monoenoic acid decreased and that of the di- and hexa-enoic acid fractions increased 
markedly with time. No trienoic acids were found in any samples of rat liver fat, in contrast to the presence of this fraction in the liver fat of the adult cock (fed or starved). The very small amount of monoenoic acid fractions of rat liver fat was in sharp contrast to the high values observed in the cock. The sums of the saturated and monoenoic acid fractions of the two species, however, appeared to be nearly the same.

\section{ISCUSSION}

Statkewitsch (1894) reported a fatty infiltration in the livers of animals that had been starved until they had lost 10-15\% of their body-weight. The results were best observed in guinea-pigs, dogs and cats, were less obvious in rabbits, and least obvious in pigeons. Mottram (1909) found a large increase in visible liver fat after $24 \mathrm{~h}$ starvation in guinea-pigs and rabbits but not in hedgehogs, rats, or pigeons. Best \& Campbell (1938) reported pronounced increases in liver fat on starvation in the guinea-pig and mouse. Harrison (1953) reported the following results for male and female rats, expressed in $\mathrm{g}$ fat $/ \mathrm{I00} \mathrm{g}$ fresh liver, for $0, \mathrm{I}, 2,4$ and 6 days of starvation: $\mathrm{I} \cdot 5, \mathrm{I} \cdot 2,2 \cdot 7$, $2 \cdot 4$ and $2 \cdot 3$ for the males and $0.6,1 \cdot 5,2 \cdot 5,3.5$ and 5.4 for the females. Various studies have shown that this excessive fat comes principally, if not entirely, from the body fat depots (Mottram, 1909; Dible, I932; Hodge, MacLachlan, Bloor, Stoneburg, Oleson \& Whitehead, 1941; Barrett, Best \& Ridout, 1938). Many other reports could be cited to demonstrate that there are species differences in the development of a fatty liver during starvation.

The development during starvation of a fatty liver condition in some species but not in others should be explainable on the basis of differences in utilization of carbohydrate and fat reserves. Our results demonstrate that the chicken does not develop a fatty liver. In the rat we observed a decrease in liver fat followed by a marked increase in the course of a 3 -day starvation period. Since after 3 days of starvation considerable changes in body composition had taken place, it is more appropriate to compare the 1 - and 3 -day liver fat changes than to compare the 3 -day values with those for the unstarved rats. Since the carbohydrate reserves of both chickens and rats are small, the species difference in liver fat content during starvation is most likely the result of a difference in fat utilization.

The differences in fatty acid composition, principally the large quantitative differences in monoenoic and saturated fatty acids, between the rat and chicken, could offer a reasonable explanation for the accumulation of liver fat in the rat, and it is suggested that the rate of desaturation may be much lower in the rat than in the chicken. It should be noted that these differences in the fatty acid composition cannot be attributed to prior dietary treatment, since both rats and chickens received essentially similar stock diets, composed largely of maize and solvent-extracted soya-bean meal with no added fat. The saturated acids are probably less readily mobilized and katabolized than monoenoic acid. In fact, desaturation to oleic acid appears to represent the first step in the katabolism of the saturated acids (Leathes \& MeyerWedell, I909; Deuel, 1957).

Possibly the most remarkable change observed in these studies was the selective 
retention of the more highly unsaturated fatty acids in the livers of the starved growing chickens. Even though these fatty acid fractions increased both as a percentage of total fatty acids and as a proportion of liver weight, there was no de novo synthesis of these acids. On the contrary, calculations showed that there were slight decreases in all of these fractions expressed as a proportion of liver weight. This means that the relative increases exhibited were merely due to a concentration of the selectively retained fatty acids. This phenomenon has been demonstrated in a general way once before. Terroine (1914) examined the fatty acids remaining in animals that had died of starvation. He found a remarkably constant amount present; the fatty acids remaining were much more unsaturated than the fatty acids found in normal animals.

\section{SUMMARY}

I. Growing chickens and adult cocks were starved for 5 days. Adult female rats were starved for 3 days. Fatty acid changes in the liver were studied during these starvation periods.

2. Neither the growing chicken nor adult cock developed a fatty liver during a 5-day starvation period.

3. The fatty acid composition of the liver fat of the growing chicken during starvation was characterized by a selective concentration of the more highly unsaturated fatty acids (four and six double bonds).

4. It was found that the adult rat had a very high level of saturated and a very low level of monoenoic acid in its liver fat. The adult cock had a much lower level of saturated and a much higher level of monoenoic acid in its liver fat. The sums of the two fractions in the two species were, however, almost equal.

5. It is suggested that the rate of desaturation (which is the preliminary step in katabolism of saturated fatty acids) in the rat is much lower than in the cock, which would account for the difference in liver fat content during starvation between these species.

\section{REFERENCES}

Association of Official Agricultural Chemists (1955). Official Methods of Analysis, 8th ed. Washington,

D.C. : Association of Official Agricultural Chemists.

Barrett, H. M., Best, C. H. \& Ridout, J. H. (1938). F. Physiol. 93, 367.

Best, C. H. \& Campbell, J. (1938). F. Physiol. 92, 91.

Best, C. H. \& Ridout, J. H. (1938-9). F. Physiol. 94, 47.

Deuel, H. J. Jr. (1957). The Lipids. New York: Interscience Publishers Inc.

Dible, J. H. (1932). F. Path. Bact. 35, 45 I.

Gabuzda, G. J. (1958). Amer. F. clin. Nutr. 6, 280.

Gershoff, S. N., Andrus, S. B. \& Hegsted, D. M. (1959). F. Nutr. 68, 75.

Harrison, M. F. (1953). Biochem. F. 55, 204.

Hodge, H. C., MacLachlan, P. L., Bloor, W. R., Stoneburg, C. A., Oleson, M. C. \& Whitehead, R. (1941). F. biol. Chem. 139, 897.

Larson, C. P. (1946). Amer. Rev. Tuberc. 54, 247.

Leathes, J. B. \& Meyer-Wedell, L. (r 909). F. Physiol. 38, xxxviii.

Luddy, F. E., Barford, R. A., Riemenschneider, R. W. \& Evans, J. D. (1958). 7. biol. Chem. 232, 843.

Mottram, V. H. (1909). F. Physiol. 38, 28 r.

Statkewitsch, P. (1894). Arch. exp. Path. 33, 415.

Summers, J. D. \& Fisher, H. (1960). F. Nutr. 72, 153.

Terroine, E. F. (1914). C.R. Acad. Sci., Paris, 159, r05. Quoted in Chem. Abstr. 8, 3318. 